\title{
Reforms win praise, but not patrons
}

\section{London \& Washington}

The United Nations Educational Scientific and Cultural Organization (UNESCO) has begun to restore its tarnished reputation. But it appears unlikely that even a spate of reports attesting to its improved efficiency and professionalism can regain its lost patrons, in particular the United States and Britain, and accomplish the goals set by its directorgeneral, Spanish biochemist Federico Mayor.

Two weeks ago, a report compiled by Knut Hammarskjöld, formerly head of the International Air Transport Association, and Peter Wilenski, Australia's permanent representative at the United $\mathrm{Na}$ tions, praised Mayor for removing much of the waste and cronyism that characterized UNESCO under the 13-year reign of his Senegalese predecessor, AmadouMahtar M'Bow, that ended in 1987. Next month a similarly favourable assessment is expected both in an internal report by the US Department of State and a review by the US congressional General Accounting Office, which sent a nineperson team to comb through the Parisbased agency's finances.

UNESCO officials hope that these reports will help to convince the United States and Britain, which walked out of UNESCO in 1984 and 1985, that the time is now ripe to rejoin the organization. With the former Soviet republics so far unable to take over the Soviet Union's \$30 million-a-year UNESCO subscription, the infusion of cash that the two countries would bring would be an important boost for the agency. But, for the time being at least, it seems that UNESCO will have to live with its cash-flow problem.

British officials agree that UNESCO seems to have put its worst excesses behind it, but they want to see Mayor's reforms take deeper root before agreeing to rejoin. And in the United States, a Democratic party victory in the forthcoming presidential election seems the only hope for UNESCO's proponents. That is because President George Bush remains vehemently opposed to rejoin- ing an agency that costs the United States more than $\$ 50$ million a year.

In the 1980 s, UNESCO was widely viewed as overstaffed, dependent on the services of expensive, outside consultants and lacking in any mechanisms to appoint and promote staff according to their merit. For Britain and the United States, the final straw was M'Bow's support for a programme called the New World Information and Communication Order. The new world order was intended to help developing countries to manage the flow of information to their people, but many people saw it as condoning government censorship of the media.

Hammarskjöld and Wilenski now say that Mayor has successfully implemented a new merit system for recruiting and appraising staff. In a move that is almost unheard of within the United Nations system, according to UNESCO's deputy director-general, Chatan Lal Sharma, some of the worst "non-performers" have been dismissed. Although only four staff have actually been fired, Sharma believes that other offenders within UNESCO will now quickly mend their ways. UNESCO's controversial information and communications policies are also now believed to be substantially reformed.

Most of the reforms has been carried out since 1990, when a US State Department report charged that Mayor had made little headway in imposing changes on a staff still dominated by people appointed by M'Bow (see Nature 344, 801; 1990). And the Hammarskjöld and Wilenski report warns that the progress could "easily regress" without strong backing from UNESCO's member states.

"It's like losing weight," says Sharma - early progress can be easily wiped out by a lapse in self-control. He says that it may take another two or three years for Mayor's reforms to become "institutionalized", with the first task being to introduce a promised system to award able staff with rapid promotion.

UNESCO staff accept that the recent reforms will not win over the current US Administration, despite support for the

\section{Explosion kills two}

A DEPTH-CHARGE used in a secret US Navy oceanographic experiment exploded last week aboard a research ship off the coast of Washington State, killing two crew members. Although the Navy would not disclose the nature of the classified research, the operations were being conducted by a team of researchers from Johns Hopkins University's Applied Research Laboratory (APL). The laboratory con- ducts seismic and ocean-floor mapping experiments for the Navy using the Amy Chouest, a chartered 265-foot research vessel.

None of the APL researchers was injured in the explosion, which occurred when the ship was about 13 miles offshore. The cause of the explosion has not yet been identified.

Christopher Anderson agency from public figures such as Frank Press, president of the National Academy of Sciences. But there is a mood of optimism within UNESCO about the prospects for a British change of heart.

British officials say that they are also pleased with recent progress. In particular, they are encouraged by a plan to give a subpanel of UNESCO's policymaking executive board a greater role in overseeing the agency's finances and administration.

Starting next year, the full executive board will be made up of representatives accountable directly to their individual governments. At present, says one British official, UNESCO's policy is decided by a collection of "throbbing great brains". Although they are appointed because of their intellectual credentials, they face little pressure to steer the agency in the direction desired by its member states.

Nevertheless, Britain intends to take a 'wait-and-see' attitude before making a decision on UNESCO (although, as in the United States, a new government could bring a change of policy). British officials want more evidence that the member states will spend UNESCO's tight budget on a smaller number of priority areas, such as basic education in developing countries and scientific programmes related to global change. $\mathrm{Al}-$ though some progress has been made, there is general agreement that UNESCO's resources are still spread too thinly. Achieving the correct balance will require many of UNESCO's member states to accept that their own pet projects do not necessarily deserve money from UNESCO's budget.

The agency's two-year budget for 1992 and 1993 is less than that of many US universities, totalling only $\$ 443$ million. More than half comes from external sources such as the UN Development Programme, rather than subscriptions from member states. With Russia, Ukraine and Belarus having taken over the former Soviet Union's UNESCO membership, but not so far its subscription, even the $\$ 15$ million a year that Britain would be charged for membership would provide an important fillip for the agency.

Sharma plays down UNESCO's cashflow problems, saying that many UN agencies face the same difficulty. In any case, he says, UNESCO is able to borrow more than $\$ 60$ million if it needs the money. But given the uncertainty surrounding the economic future of the former Soviet republics, the wisdom of taking such a course must be questioned.

Peter Aldhous 8 Christopher Anderson 